irregular in shape, and lack the features characteristic of the AHT starches (Fig. 2f, g).

It is also clear that using specific grain types together with attribute combinations in a multiple grain analysis is an effective and perhaps the most conservative means to distinguish individual genera and species. Such an approach employs all the morphological characteristics that account for the population of starches in a single species as well as their quantitative frequency tendencies, and it takes into account intraand interspecific variation in grain attributes. For example, starch grain populations from T. dicoccoides contain high proportions (about 40\%) of grains that have distinctive, large crater-like impressions on the surface; these grains are also without lamellae (Fig. 2a).

These types were not observed in either Hordeum or Aegilops, which, in turn contributed high frequencies of other types of characteristic starch grains (Fig. 2b-e and

Supplementary Figs 1-4). In archaeological starch grain assemblages of sufficient sample sizes it would be possible to identify the presence and/or probable absence or low frequency of individual genera and species using these kinds of signatures.

Other families and species represented through their carbonized remains at Ohalo II were: Asteraceae (Centaurea pallescens Delile, Silybum marianum (L.) Gaertner),

Chenopodiaceae (Atriplex halimus L., Suaeda aegyptiaca (Hasselquist) Zohary), Fabaceae (Melilotus indicus (L.) Allioni, Pisum elatius Marschall von Bieberstein), Malvaceae (Malva aegyptia L.), Potamogetonaceae (Potamogeton pectinatus L., Potamogeton perfoliatus L.), Ruppiaceae (Ruppia maritima L.) and Zygophyllaceae (Nitraria schoberi L.). Most of these species produced oils and not starches. The taxa with starches (Pisum, Potamogeton and Ruppia) have grains that can be distinguished from others in our and other established reference collections (Supplementary Figs 5-7).

Received 4 May; accepted 4 June 2004; doi:10.1038/nature02734.

1. Zohary, D. \& Hopf, M. Domestication of Plants in the Old World, 3rd edn (Oxford Science Publications, Oxford, 2000).

2. Nadel, D. Ohalo II-A 23,000-Year-Old Fisher-Hunter-Gatherers' Camp on the Shore of the Sea of Galilee (Catalogue No. 20, Hecht Museum, Univ. Haifa, Haifa, 2002).

. Nadel, D. \& Werker, E. The oldest ever brush hut plant remains from Ohalo II, Jordan Valley, Israel. Antiquity 73, 755-764 (1999).

4. Nadel, D., Carmi, I. \& Segal, D. Radiocarbon dating of Ohalo II: Archaeological and methodological implications. J. Archaeol. Sci. 22, 811-822 (1995)

. Kislev, M. E., Nadel, D. \& Carmi, I. Epipaleolithic (19,000 вP) cereal and fruit diet at Ohalo II, Sea of Galilee, Israel. Rev. Palaeobot. Palynol. 73, 161-166 (1992).

6. Weiss, E., Kislev, M. E., Simchoni, O. \& Nadel, D. Small-grained wild grasses as staple foods at the 23,000 year old site of Ohalo II, Israel. Econ. Bot. (in the press).

7. Piperno, D. R., Ranere, A. J., Holst, I. \& Hansell, P. Starch grains reveal early root crop horticulture in the Panamanian tropical forest. Nature 407, 894-897 (2000).

8. Pearsall, D. M., Chandler-Ezell, K. \& Zeidler, J. A. Maize in ancient Ecuador: Results of residue analysis of stone tools from the Real Alto site. J. Archaeol. Sci. 31, 423-442 (2004).

9. Palmer, C. Milk and cereals; identifying food and food identity among Fellahin and Bedouin in Jordan. Levant 34, 173-195 (2002).

10. Hobbs, J. J. Bedouin Life in the Egyptian Wilderness (Univ. of Texas Press, Austin, 1992).

11. Nicolaisem, J. Ecology and Culture of the Pastoral Tuareg (Copenhagen National Museum, Copenhagen, 1963).

12. Jenkins, D. J. A. et al. Glycemic index: overview of implications in health and disease. Am. J. Clin. Nutr. 76, 266-273 (2002).

13. Foster-Powell, K., Holt, S. H. \& Brand-Miller, J. C. International table of glycemic index and glycemic load values. Am. J. Clin. Nutr. 76, 5-56 (2002).

14. Stahl, A. in Foraging and Farming (eds Harris, D. R. \& Hillman, G. C.) 171-194 (Unwin Hyman, London, 1989).

15. Wright, K. Ground-Stone tools and hunter-gatherer subsistence in southwest Asia: Implications for the transition to farming. Am. Antiq. 59, 238-263 (1994).

16. Kuhn, S. L. \& Stiner, M. C. in Hunter-Gatherers: An Interdisciplinary Perspective (eds Painter-Brick, C. Layton, R. H. \& Rowley-Conwy, P.) 99-142 (Cambridge Univ. Press, Cambridge, 2001).

17. Bar-Yosef, O. \& Kislev, M. E. in Foraging and Farming: The Evolution of Plant Exploitation (eds Harris, D. R. \& Hillman, G. C.) 633-642 (Unwin Hyman, London, 1989).

18. Flannery, K. V. in The Domestication and Exploitation of Plants and Animals (eds Ucko, P. J. \& Dimbleby, G. W.) 73-100 (Duckworth, London, 1969).

19. Hawkes, K., O'Connell, J. F. \& Rogers, L. The behavioral ecology of modern hunter-gatherers, and human evolution. Trends Ecol. Evol. 12, 29-32 (1997).

20. Kennett, D. \& Winterhalder, B. in Foraging Theory and the Transition to Agriculture (eds Kennett, D. \& Winterhalder, B.) (Smithsonian Institution Press, Washington DC, in the press).

21. Weiss, E., Wetterstrom, W., Nadel, D. \& Bar-Yosef, O. The broad spectrum revolution revisited: Evidence from plant remains. Proc. Natl Acad. Sci. USA 101, 9551-9555 (2004).

22. Bar-Yosef, O. From sedentary foragers to village hierarchies: The emergence of social institutions. Proc. Br. Acad. 110, 1-38 (2001)

23. Reichert, E. T. The Differentiation and Specificity of Starches in Relation to Genera, Species, Etc. (Carnegie Institution of Washington, Washington DC, 1913).

24. Seidemann, J. Starke Atlas (Paul Parey, Berlin, 1966).

25. Cortello, A. R. \& Pochettino, M. L. Starch grain analysis as a microscopic identification feature in the identification of plant material. Econ. Bot. 48, 171-181 (1994).

26. Perry, L. Starch analyses reveal the multiple functions of quartz 'manioc' grater flakes from the Orinoco Basin, Venezuela. Interciencia 27, 635-639 (2002).

27. Piperno, D. R. \& Holst, I. The presence of starch grains on prehistoric stone tools from the lowland Neotropics: Indications of early tuber use and agriculture in Panama. J. Archaeol. Sci. 25, 765-776 (1998).

28. Torrence, R., Wright, R. \& Conway, R. Identification of starch granules using image analysis and multivariate techniques. J. Archaeol. Sci. 31, 519-532 (2004).

Supplementary Information accompanies the paper on www.nature.com/nature.
Acknowledgements Supported by the Smithsonian Tropical Research Institute (STRI), a grant to the STRI from the Andrew W. Mellon Foundation, the American School of Prehistoric Research (Peabody Museum), Harvard University and the National Museum of Natural History. We acknowledge the help of the following people and institutions for supplying the seed reference collection used in this study: E. Wood and D. Pfister (Harvard University Herbarium), the United States National Plant Germplasm System (North Central Regional Plant Introduction Station, Western Regional Plant Introduction Station and Plant Genetic Resources Conservation Unit), and the Royal Botanic Gardens, Kew (Seed Conservation Department). The Ohalo II project was supported by the Irene-Levi Sala CARE Archaeological project Foundation, the Israel Academy of Science, the Jerusalem Center for Anthropological Studies, the L.S.B. Leakey Foundation, the M. Stekelis Museum of Prehistory in Haifa, the MAFCAF Foundation, the National Geographic Society and the Israel Antiquities Authority.

Competing interests statement The authors declare that they have no competing financial interests.

Correspondence and requests for materials should be addressed to D.R.P.

(pipernod@tivoli.si.edu) and E.W. (eweiss@fas.harvard.edu).

\section{Effect of trace metal availability on coccolithophorid calcification}

\section{K. G. Schulz ${ }^{1,2}$, I. Zondervan ${ }^{1}$, L. J. A. Gerringa ${ }^{3}$, K. R. Timmermans ${ }^{3}$, M. J. W. Veldhuis ${ }^{3}$ \& U. Riebesell ${ }^{1,2}$}

${ }^{1}$ Alfred Wegener Institute for Polar and Marine Research, PO Box 120161, 27515 Bremerhaven, Germany

${ }^{2}$ Leibniz Institute for Marine Sciences (IFM-GEOMAR), Düsternbrooker Weg 20, 24105 Kiel, Germany

${ }^{3}$ Royal Netherlands Institute for Sea Research, PO Box 59, 1790 AB Den Burg, Texel, The Netherlands

The deposition of atmospheric dust into the ocean has varied considerably over geological time ${ }^{1,2}$. Because some of the trace metals contained in dust are essential plant nutrients which can limit phytoplankton growth in parts of the ocean, it has been suggested that variations in dust supply to the surface ocean might influence primary production ${ }^{3,4}$. Whereas the role of trace metal availability in photosynthetic carbon fixation has received considerable attention, its effect on biogenic calcification is virtually unknown. The production of both particulate organic carbon and calcium carbonate $\left(\mathrm{CaCO}_{3}\right)$ drives the ocean's biological carbon pump. The ratio of particulate organic carbon to $\mathrm{CaCO}_{3}$ export, the so-called rain ratio, is one of the factors determining $\mathrm{CO}_{2}$ sequestration in the deep ocean. Here we investigate the influence of the essential trace metals iron and zinc on the prominent $\mathrm{CaCO}_{3}$-producing microalga Emiliania huxleyi. We show that whereas at low iron concentrations growth and calcification are equally reduced, low zinc concentrations result in a de-coupling of the two processes. Despite the reduced growth rate of zinc-limited cells, $\mathrm{CaCO}_{3}$ production rates per cell remain unaffected, thus leading to highly calcified cells. These results suggest that changes in dust deposition can affect biogenic calcification in oceanic regions characterized by trace metal limitation, with possible consequences for $\mathrm{CO}_{2}$ partitioning between the atmosphere and the ocean.

The production of $\mathrm{CaCO}_{3}$ in the surface ocean, its export to greater depths and its deposition in the sediment above the lysocline (the depth below which $\mathrm{CaCO}_{3}$ dissolves) affect atmospheric $\mathrm{CO}_{2}$ in two ways. On a timescale that is shorter than the ocean mixing time, $\mathrm{CaCO}_{3}$ export reduces alkalinity in the surface ocean and lowers its storage capacity for atmospheric $\mathrm{CO}_{2}$. On a timescale of thousands of years, a mechanism called carbonate compensation balances $\mathrm{CaCO}_{3}$ burial with its supply of raw materials (riverine calcium and carbonate ions) by adjusting the depth of the lysocline $e^{5}$. This determines the deep ocean's carbonate ion concentration and 
controls surface water carbonate chemistry and consequently atmospheric $\mathrm{CO}_{2}$. On both timescales a reduction in $\mathrm{CaCO}_{3}$ export lowers $\mathrm{CO}_{2}$ concentrations in the atmosphere.

$\mathrm{CaCO}_{3}$ is predominantly produced in the open ocean, to a large extent by coccolithophores ${ }^{6}$. These open-ocean areas are subject to strong changes in atmospheric trace metal deposition. The rates for both iron and zinc deposition are probably up to ten times lower in today's ocean compared with the glacial ocean (see ref. 1 and references therein for iron, and Fig. 1 for zinc). Today iron concentrations limit phytoplankton productivity in large parts of the ocean known as high nitrate low chlorophyll (HNLC) areas ${ }^{7}$. Outside these regions iron availability is generally sufficient for most primary producers; however, productivity is often limited by the macronutrient nitrogen ${ }^{8}$. Although the significance of openocean zinc limitation awaits further assessment, prevailing zinc concentrations have been found to limit phytoplankton growth ${ }^{9}$, particularly that of coccolithophores ${ }^{10}$.

To simulate open-ocean iron and zinc limitation and to examine their effect on biogenic calcification, the prominent $\mathrm{CaCO}_{3}$ producer E. huxleyi was grown under well-defined trace metal conditions, using the trace metal chelator EDTA and varying additions of iron chloride $\left(\mathrm{FeCl}_{3}\right)$ or zinc chloride $\left(\mathrm{ZnCl}_{2}\right)$. Because E. huxleyi has the ability to substitute cobalt for zinc ${ }^{11}$, cells were grown at low free cobalt concentrations $\left(\left[\mathrm{Co}^{2+}\right]\right)$ of about $0.2 \mathrm{pmol} \mathrm{kg}^{-1}$, which are comparable to values found in open-ocean waters ${ }^{12}$. Furthermore, because marine biogenic calcification is sensitive to $\mathrm{CO}_{2}$-related changes in seawater carbonate chemistry ${ }^{13}$, which has varied in parallel with atmospheric trace metal deposition ${ }^{1}$, incubations were carried out at different $\mathrm{CO}_{2}$ concentrations.

The effect of iron on calcification was tested in incubations covering a range of calculated $\left[\mathrm{Fe}(\mathrm{III})^{\prime}\right]$ (total dissolved inorganic iron(III) species) between $0.06-360 \mathrm{pmol} \mathrm{kg}^{-1}$, at $\mathrm{CO}_{2}$ concentrations of 20 and $7 \mu \mathrm{mol} \mathrm{kg}^{-1}$ ( $\mathrm{pH} \sim 7.9$ and $\sim 8.35$, respectively). The instantaneous growth rate decreased with decreasing [ $\left[\mathrm{Fe}(\mathrm{III})^{\prime}\right]$ and was half-saturated at $\sim 0.7 \mathrm{pmol} \mathrm{kg}^{-1}$ (Fig. 2a). Over the observed range neither the $\mathrm{CaCO}_{3}$ content per cell (Fig. 2b) nor the cellular $\mathrm{CaCO}_{3}$ to nitrogen ratio (Fig. 2d) changed significantly; however, the $\mathrm{CaCO}_{3}$ production rate per cell decreased about sixfold with decreasing $\left[\mathrm{Fe}(\mathrm{III})^{\prime}\right]$ (Fig. 2c), proportionally with the growth rate.

In a second experiment the effect of zinc on calcification was studied. Four different $\left[\mathrm{CO}_{2}\right]$ of $30,20,13$ and $7 \mu \mathrm{mol} \mathrm{kg}^{-1}(\mathrm{pH}$

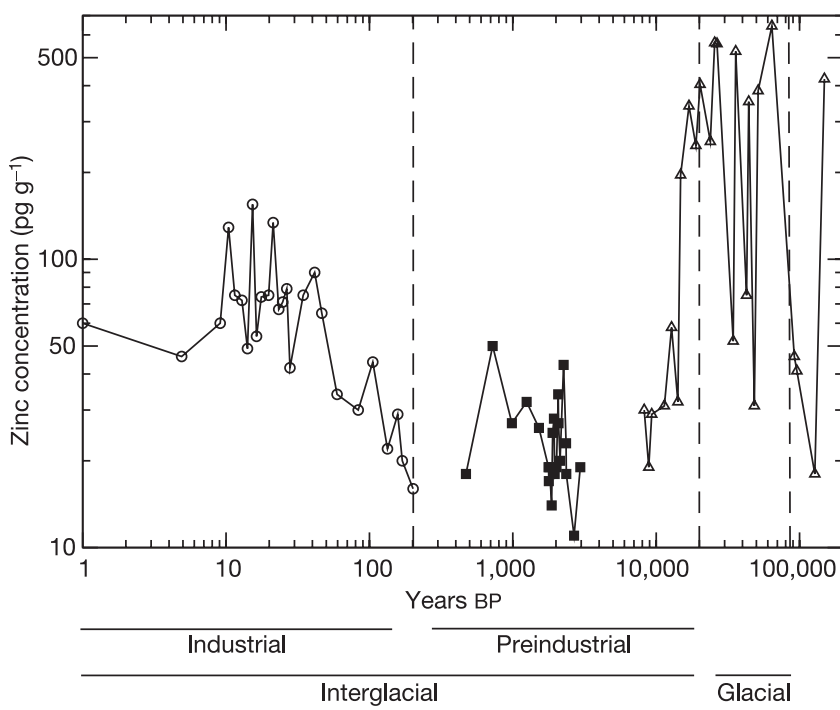

Figure 1 Zinc concentration in central Greenland snow and ice over the past 150,000 years. Data compiled from previous research: ref. 28, circles; ref. 29, squares; and ref. 30, triangles. $\sim 7.75, \sim 7.9, \sim 8.1$ and $\sim 8.35$, respectively) were applied and the calculated free zinc concentration $\left(\left[\mathrm{Zn}^{2+}\right]\right)$ ranged from 0.3 to $6 \mathrm{pmol} \mathrm{kg}{ }^{-1}$. The instantaneous growth rate decreased with decreasing $\left[\mathrm{Zn}^{2+}\right]$ and was half-saturated at $\sim 0.5 \mathrm{pmol} \mathrm{kg}^{-1}$ (Fig. 3a), in close agreement with the previously determined value of $\sim 0.6 \mathrm{pmol} \mathrm{kg}^{-1}$ (ref. 11). At the same time, the amount of $\mathrm{CaCO}_{3}$ per cell increased from 10 to almost $60 \mathrm{pg}$ with decreasing $\left[\mathrm{Zn}^{2+}\right]$ (Fig. 3b). This was confirmed by scanning electron microscopy, which showed that cells of E. huxleyi were covered with multiple layers of calcite platelets (coccoliths) under zinc-depleted conditions, compared with 1-2 layers of coccoliths at high $\left[\mathrm{Zn}^{2+}\right]$ (Fig. $4 \mathrm{a}$ and b, respectively). The ratio of cellular $\mathrm{CaCO}_{3}$ to nitrogen increased more than twofold, from about four at high $\left[\mathrm{Zn}^{2+}\right]$ to approximately nine at low $\left[\mathrm{Zn}^{2+}\right]$ (Fig. 3d). In contrast, the $\mathrm{CaCO}_{3}$ production rate per cell was hardly affected (Fig. 3c).

In the iron experiment, higher $\mathrm{CaCO}_{3}$ contents and production rates per cell were observed at low $\left[\mathrm{CO}_{2}\right]$, consistent with previous findings ${ }^{14}$ (Fig. 2b, c). Owing to the massive zinc-related response of the cellular $\mathrm{CaCO}_{3}$ content (Fig. 3b) and the comparatively high variability within and between $\mathrm{CO}_{2}$ treatments, the relatively small effect of carbonate chemistry on calcification could not be detected in the zinc assay.

The observed differences in calcification between iron- and zinclimited cells may reflect the different roles of the two micronutrients in cellular processes. Although zinc deficiency slows down cellular growth and nitrogen utilization rates, it does not significantly affect the rate of $\mathrm{CaCO}_{3}$ production (Fig. 3c). The resulting de-coupling of growth and calcification causes $\mathrm{CaCO}_{3}$ accumulation in slowgrowing cells of E. huxleyi (Fig. 3b). This also leads to a steady increase in the cellular $\mathrm{CaCO}_{3}$ to nitrogen ratio when changing from high to low $\left[\mathrm{Zn}^{2+}\right]$ (Fig. $3 \mathrm{~d}$ ). On the contrary, iron depletion not only reduces growth and nitrogen utilization rates, but equally reduces the rate of cellular $\mathrm{CaCO}_{3}$ production (Fig. 2c). Therefore, the cellular $\mathrm{CaCO}_{3}$ to nitrogen ratio remains fairly constant with varying iron availability (Fig. 2 d).

a
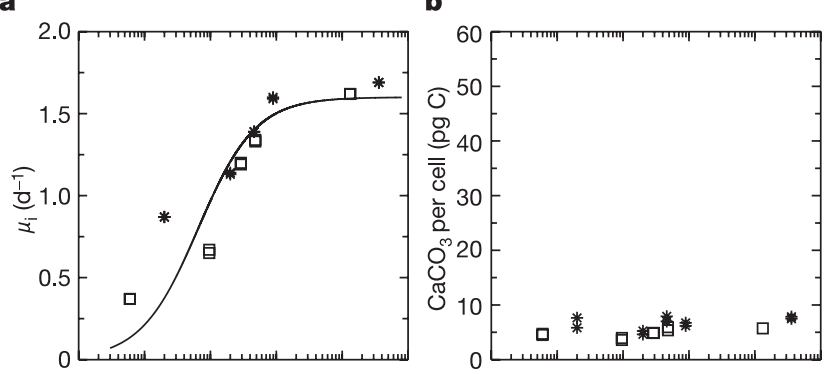

c
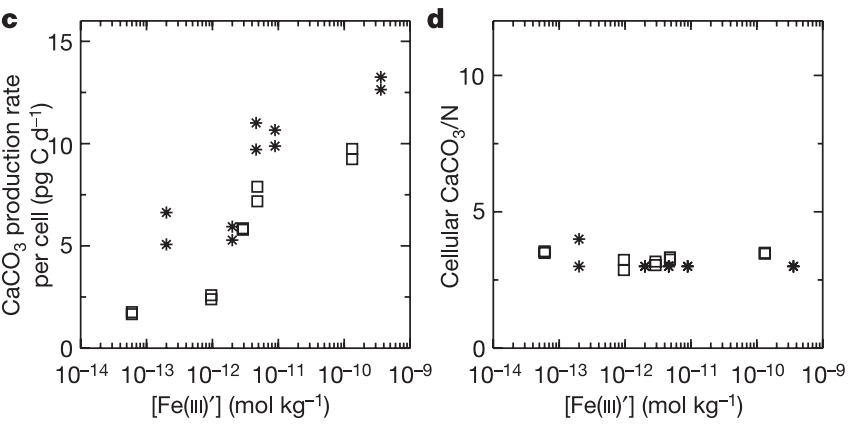

Figure 2 Response of $E$. huxleyi to varying free iron concentrations ([ $\left.\left.\mathrm{Fe}^{\prime}(\mathrm{III})\right]\right)$. Responses shown are instantaneous growth rate $\left(\mu_{i}\right)(\mathbf{a}), \mathrm{CaCO}_{3}$ content per cell $(\mathbf{b})$, the specific $\mathrm{CaCO}_{3}$ production rate per cell and day $(\mathbf{c})$ and the ratio of cellular $\mathrm{CaCO}_{3}$ to nitrogen (d). The solid line in a was obtained by fitting the data nonlinearly to a modified Monod curve, which accounts for a cell's minimum free metal requirement. The squares and asterisks denote $\mathrm{CO}_{2}$ concentrations of 20 and $7 \mu \mathrm{mol} \mathrm{kg}^{-1}$, respectively. 
a

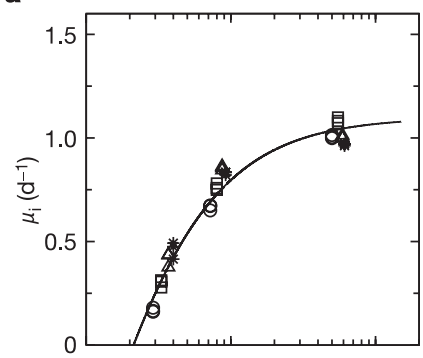

c

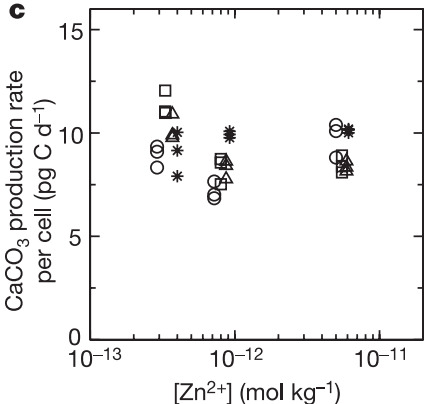

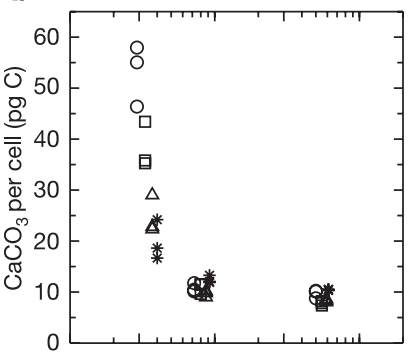

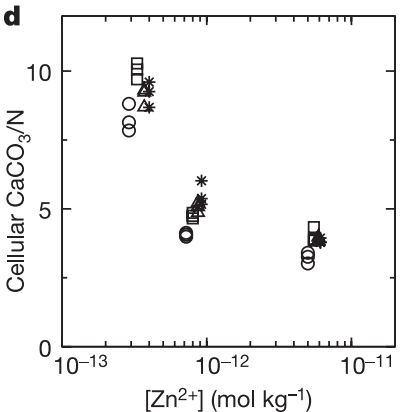

Figure 3 Response of $E$. huxleyi to varying free zinc concentrations $\left(\left[\mathrm{Zn}^{2+}\right]\right)$. a-d, As Fig. 2. The symbols denote four $\mathrm{CO}_{2}$ concentrations as follows: circles, 30; squares, 20; triangles, 13 ; and asterisks, $7 \mu \mathrm{mol} \mathrm{kg}{ }^{-1}$. Note that the lower maximum growth rate in this experiment compared with the iron experiment (Fig. 2a) was due to the lack of the vitamin thiamine. A control experiment with thiamine added at selected $\left[\mathrm{Zn}^{2+}\right]$ (data not shown) resulted in the same trends at higher $\mu_{\mathrm{i}}$.

The biogeochemical relevance of the observed responses to iron and zinc limitation is likely to differ between oceanic regions. Increased atmospheric deposition of iron and zinc in the ocean's HNLC areas during glacial times has probably not significantly altered global $\mathrm{CaCO}_{3}$ production. For reasons not fully understood, pelagic calcification is only of minor importance in these regions. In the largest $\mathrm{HNLC}$ region, the Southern Ocean, $\mathrm{CaCO}_{3}$ production seems to be negligible ${ }^{6}$. This is also true for the equatorial Pacific, which is dominated by siliceous primary production, as is clearly reflected in the underlying sediments ${ }^{15}$ above the lysocline. Only in the iron-deficient Pacific above $45^{\circ} \mathrm{N}$ does $\mathrm{CaCO}_{3}$ production match that in the rest of the North Pacific ${ }^{6}$. As this area is comparatively small, however, its contribution to global calcification is bound to be low. Additionally, in HNLC areas diatoms have been shown to benefit most from iron or combined iron and zinc additions (see refs 9, 10 and references therein) by increasing nitrogen utilization and biomass production.

Outside the HNLC areas, export production is limited by the supply of macronutrients, primarily nitrate ${ }^{8}$. In many of these areas total dissolved zinc concentrations (see refs 16, 17 and references therein) are as low as those found in parts of the North Pacific ${ }^{18}$, where coccolithophorid growth has been shown to be limited by zinc $^{10}$. Considering that in the present ocean up to $450 \mu \mathrm{g} \mathrm{m}^{-2}$ dissolvable zinc is deposited atmospherically per year ${ }^{19}$ compared with $1,000 \mu \mathrm{g} \mathrm{m}^{-2}$ zinc per year which is upwelled (taking a deepocean zinc concentration of $5.4 \mathrm{nmol} \mathrm{kg}^{-1}$ and a mean deep-surface water exchange volume of $3 \mathrm{~m}^{3} \mathrm{~m}^{-2}$ per year ${ }^{15}$ ), a tenfold increase (Fig. 1) in atmospheric deposition can be expected to significantly alter surface ocean zinc concentrations. Moreover, Northern Hemisphere atmospheric zinc deposition in the recent pre-industrial period was probably one-half to one-third of that today, as indicated by zinc measurements taken in Arctic ice and snow (Fig. 1). Thus, regions in which growth of coccolithophores is potentially zinclimited today probably experienced significant alleviation during glacial times.

There are two ways in which changes in zinc supply to the surface
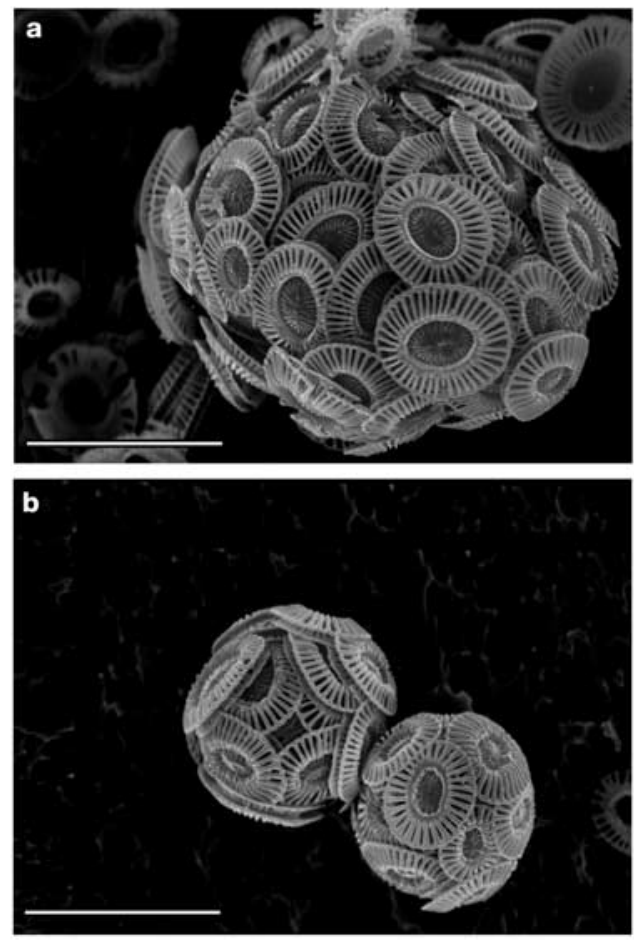

Figure 4 Scanning electron microscopy images of $E$. huxleyi grown under different free zinc and $\mathrm{CO}_{2}$ concentrations. a, $0.3 \mathrm{pmol} \mathrm{kg}{ }^{-1}\left[\mathrm{Zn}^{2+}\right]$ and $20 \mu \mathrm{mol} \mathrm{kg}^{-1}\left[\mathrm{CO}_{2}\right]$. b, 6 pmol kg ${ }^{-1}\left[\mathrm{Zn}^{2+}\right]$ and $13 \mu \mathrm{mol} \mathrm{kg}{ }^{-1}\left[\mathrm{CO}_{2}\right]$. Scale bars, $5 \mu \mathrm{m}$. Note that the effect of $\mathrm{CO}_{2}$ on calcification is minute compared with that of zinc. See text for details.

ocean by means of atmospheric dust deposition could alter global $\mathrm{CaCO}_{3}$ production on glacial/interglacial timescales. On the one hand, results of a recent study ${ }^{10}$ indicate that alleviation of zinc limitation may be accompanied by changes in the natural phytoplankton assemblages in favour of coccolithophores. This would lead to higher coccolithophorid-based biomass and potentially higher total $\mathrm{CaCO}_{3}$ production at the community level. The results of this study, on the other hand, indicate that the amount of $\mathrm{CaCO}_{3}$ that is precipitated in conjunction with a given amount of coccolithophorid biomass produced is expected to decrease with increasing surface-water zinc concentrations. On the basis of this effect, higher atmospheric zinc deposition during glacial periods would correspond to lower $\mathrm{CaCO}_{3}$ production.

If coccolithophorid zinc limitation proves to be a general phenomenon in today's oceans, the observed processes may influence the strength of the ocean's $\mathrm{CaCO}_{3}$ pump. Any change in its intensity directly affects the rain ratio, thereby altering carbon sequestration in the ocean. Long-term variation in atmospheric zinc deposition and its potential effect on biogenic calcification may therefore need to be considered in the context of glacial/interglacial changes in $\mathrm{CO}_{2}$ partitioning between atmosphere and ocean.

\section{Methods}

\section{Experimental setup}

Mono-specific cultures of E. huxleyi clone PML B92/11 were grown in triplicates (zinc experiment) or duplicates (iron experiment) at $15^{\circ} \mathrm{C}$ in $0.2 \mu \mathrm{m}$ filtered sea water, originating from the Gulf of Biscay (zinc experiment) and the Antarctic Ocean (iron experiment), at a photon flux density of $180 \mu \mathrm{mol} \mathrm{m}^{-2} \mathrm{~s}^{-1}$ (supplied from cool white fluorescent bulbs (Philips TLD 36W/54) on a 16/8-h light/dark cycle). Precultures and experimental incubations in dilute batch cultures ensured exponential growth throughout the experiment. The medium was enriched with nitrate and phosphate (64 and $4 \mu \mathrm{mol} \mathrm{kg}^{-1}$, respectively), vitamin B12 $\left(0.59 \mathrm{nmol} \mathrm{kg}^{-1}\right)$, biotin $\left(0.2 \mathrm{nmol} \mathrm{kg}^{-1}\right)$ and $59 \mathrm{nmol} \mathrm{kg}{ }^{-1}$ of thiamine-HCl (see Fig. 3 legend for details). Final trace metal concentrations were obtained by adding: $\mathrm{FeCl}_{3}\left(1 \mu \mathrm{mol} \mathrm{kg}{ }^{-1}\right)$ (zinc experiment), $\mathrm{ZnCl}_{2}$ $\left(1 \mu \mathrm{mol} \mathrm{kg}^{-1}\right)$ (iron experiment), $\mathrm{CuSO}_{4} \cdot 5 \mathrm{H}_{2} \mathrm{O}\left(40 \mathrm{nmol} \mathrm{kg}{ }^{-1}\right), \mathrm{CoCl}_{2}\left(10 \mathrm{nmol} \mathrm{kg}{ }^{-1}\right)$, $\mathrm{MnCl}_{2} \cdot 4 \mathrm{H}_{2} \mathrm{O}\left(450 \mathrm{nmol} \mathrm{kg}{ }^{-1}\right),\left(\mathrm{NH}_{4}\right)_{6} \mathrm{Mo}_{7} \mathrm{O}_{24} \cdot 4 \mathrm{H}_{2} \mathrm{O}\left(1.43 \mathrm{nmol} \mathrm{kg}{ }^{-1}\right), \mathrm{Na}_{2} \mathrm{SeO}_{3} \cdot 5 \mathrm{H}_{2} \mathrm{O}$ 
( $\left.100 \mathrm{nmol} \mathrm{kg}{ }^{-1}\right), \mathrm{KBr}\left(92 \mu \mathrm{mol} \mathrm{kg}^{-1}\right), \mathrm{SrCl}_{2} \cdot 6 \mathrm{H}_{2} \mathrm{O}\left(13 \mu \mathrm{mol} \mathrm{kg}^{-1}\right), \mathrm{AlCl}_{3}$ $\left(100 \mathrm{nmol} \mathrm{kg}^{-1}\right), \mathrm{LiCl}\left(70 \mathrm{nmol} \mathrm{kg}{ }^{-1}\right), \mathrm{KI}\left(60 \mathrm{nmol} \mathrm{kg}{ }^{-1}\right), \mathrm{H}_{3} \mathrm{BO}_{3}\left(3.23 \mu \mathrm{mol} \mathrm{kg}{ }^{-1}\right), \mathrm{RbCl}$ $\left(250 \mathrm{nmol} \mathrm{kg}^{-1}\right)$. To achieve defined trace metal conditions for $\left[\mathrm{Zn}^{2+}\right]$ or $\left[\mathrm{Fe}(\mathrm{III})^{\prime}\right]$, $1 \mathrm{mmol} \mathrm{kg}{ }^{-1}$ of $\mathrm{Na}_{2} \mathrm{EDTA} \cdot 6 \mathrm{H}_{2} \mathrm{O}$ and varying amounts of $\mathrm{ZnCl}_{2}$ or $\mathrm{FeCl}_{3}$ were added to the media, which after $\mathrm{pH}$ adjustment with $\mathrm{NaOH}$ was stored for $24 \mathrm{~h}$ in the dark to allow chemical equilibration. In a control experiment at low, widely used culture media [EDTA] of $6 \mu \mathrm{mol} \mathrm{kg} \mathrm{kg}^{-1}$ the same maximum growth rates were observed, indicating that the comparatively high $[\mathrm{EDTA}]$ applied here did not have any detrimental effect on $E$. huxleyi.

\section{Trace metal speciation}

$\left[\mathrm{Zn}^{2+}\right]$ and $\left[\mathrm{Fe}(\mathrm{III})^{\prime}\right]$ were calculated from total metal concentrations using an equilibrium complexation model. Therefore, conditional stability constants for $\mathrm{Fe}(\mathrm{III})$ complexes with chlorine, fluoride, sulphate and the $\mathrm{Fe}$ (III) hydroxides (see refs 20,21 and references therein) were included and, for the sake of consistency, thermodynamic stability constants ${ }^{22}$ were used for all EDTA complexes with $\mathrm{Fe}, \mathrm{Cu}, \mathrm{Co}, \mathrm{Mn}, \mathrm{Zn}, \mathrm{Ca}, \mathrm{Mg}$, the protonated forms of EDTA, and $\mathrm{ZnCO}_{3}$ and $\mathrm{ZnSO}_{4}$ after correction for ionic strength (salinity 34 ) with ion activity coefficients obtained either by Pitzer modelling ${ }^{23}$ or Davies approximation. Light-induced photo-dissociation of Fe-EDTA complexes was accounted for following the model given in ref. 24. On the basis of this model two $\mathrm{pH}$-dependent factors, linearly interpolated to $15^{\circ} \mathrm{C}$, were calculated and corrected for the lower photonflux density and the light/dark cycle in our experiments (resulting in factors of 1.5 at $\mathrm{pH}$ 7.9 and 3 at $\mathrm{pH}$ 8.35). The absolute values for [ $\left.\mathrm{Fe}(\mathrm{III})^{\prime}\right]$, however, crucially depend on the selected set of hydrolysis constants, particularly on $\beta_{3}^{*}$, which is so far not well constrained (see Table 2 in ref. 24 and references therein for details). The total zinc and iron concentrations in the natural sea water before nutrient addition were 7 and $1 \mathrm{nmol} \mathrm{kg}{ }^{-1}$ respectively and the $\left[\mathrm{Zn}^{2+}\right] /\left[\mathrm{Zn}_{\text {total }}\right]$ in the zinc experiments was about $1 / 75,000$.

\section{Sampling and measurements}

The carbonate system was calculated from $\mathrm{pH}$ and total dissolved inorganic carbon using the dissociation constants of ref. 25 as refitted in ref. 26 . The $\mathrm{pH}$ was measured using the recommendations of ref. 21 and the total dissolved inorganic carbon was measured using a photochemical approach ${ }^{27}$. To calculate growth rates, cell counts were obtained at the beginning and end of incubations on a Coulter Epics XL-MCL flowcytometer. For measurements of cellular particulate organic carbon (POC) and nitrogen (PON) and tota particulate carbon (TPC), subsamples were filtered on precombusted $\left(500^{\circ} \mathrm{C}\right)$ Whatman $\mathrm{GF} / \mathrm{F}$ filters at the end of the experiments and stored at $-25^{\circ} \mathrm{C}$. Before analysis POC filter were fumed for $2 \mathrm{~h}$ with concentrated $\mathrm{HCl}$. POC, PON and TPC were analysed on an ANCA-SL 20-20 Europa Scientific mass spectrometer after $2 \mathrm{~h}$ of drying the filters at $60^{\circ} \mathrm{C}$ $\mathrm{CaCO}_{3}$ was calculated by subtracting POC from TPC. $\mathrm{CaCO}_{3}$ production rates were calculated from growth rates and cellular $\mathrm{CaCO}_{3}$ contents. Owing to the experimental approach used in this study (see above), these parameters did not change significantly over the course of the experiments.

Received 24 January; accepted 10 May 2004; doi:10.1038/nature02631.

Petit, J. R. et al. Climate and atmospheric history of the past 420,000 years from the Vostok ice core, Antarctica. Nature 399, 429-436 (1999).

2. Mahowald, N. et al. Dust sources and deposition during the last glacial maximum and current climate: A comparison of model results with paleodata from ice cores and marine sediments. J. Geophys. Res 104, 15895-15916 (1999).

3. Martin, J. H. Glacial-interglacial $\mathrm{CO}_{2}$ change: the iron hypothesis. Paleoceanogr. 5, 1-13 (1990).

4. Morel, F. M. M. et al. Zinc and carbon co-limitation of marine phytoplankton. Nature 369, 740-742 (1994).

Broecker, W. S. \& Peng, T.-H. The role of $\mathrm{CaCO}_{3}$ compensation in the glacial to interglacial atmospheric $\mathrm{CO}_{2}$ change. Glob. Biogeochem. Cycles 1, 15-29 (1987).

6. Milliman, J. D. Production and accumulation of calcium carbonate in the ocean: budget of a nonsteady state. Glob. Biogeochem. Cycles 7, 927-957 (1993).

7. Baar de, H. J. W. \& Boyd, P. W. in The Changing Ocean Carbon Cycle (eds Hanson, R. B., Ducklow, H. W. \& Fields, J. G.) 61-140 (Cambridge Univ. Press, Cambridge, 2000).

8. Conkright, M. E., Levitus, S. \& Boyer, T. P. World Ocean Atlas 1994, Vol. 1 Nutrients (NOAA Atlas NESDIS 1, US Department of Commerce, Washington DC, 1994)

9. Coale, K. H. Effects of iron, manganese, copper, and zinc enrichments on productivity and biomass in the subarctic Pacific. Limnol. Oceanogr. 36, 1851-1864 (1991).

10. Crawford, D. W. et al. Influence of zinc and iron enrichments on phytoplankton growth in the northeastern subarctic Pacific. Limnol. Oceanogr. 48, 1583-1600 (2003).

11. Sunda, W. G. \& Huntsman, S. A. Cobalt and zinc interreplacement in marine phytoplankton: Biological and geochemical implications. Limnol. Oceanogr. 40, 1404-1417 (1995).

12. Ellwood, M. J. \& Van den Berg, C. M. G. Determination of organic complexation of cobalt in seawater by cathodic stripping voltammetry. Mar. Chem. 75, 33-47 (2001).

13. Riebesell, U. et al. Reduced calcification of marine plankton in response to increased atmospheric $\mathrm{CO}_{2}$. Nature 407, 364-367 (2000)

14. Zondervan, I., Rost, B. \& Riebesell, U. Effect of $\mathrm{CO}_{2}$ concentration on the PIC/POC ratio in the coccolithophore Emiliania huxleyi grown under light-limiting conditions and different daylengths. J. Exp. Mar. Biol. Ecol. 272, 55-70 (2002).

15. Broecker, W. S. \& Peng, T.-H. Tracers in the Sea (Eldigio, New York, 1982).

16. Bruland, K. W. Complexation of zinc by natural organic ligands in the central North Pacific. Limnol. Oceanogr. 34, 269-285 (1989).

17. Kremling, K. \& Streu, P. The behaviour of dissolved Cd, Co, $\mathrm{Zn}$ and $\mathrm{Pb}$ in North Atlantic near-surface waters $\left(30^{\circ} \mathrm{N} / 60^{\circ} \mathrm{W}-60^{\circ} \mathrm{N} / 2^{\circ} \mathrm{W}\right)$. Deep-Sea Res. I 48, 2541-2567 (2001).

18. Lohan, M. C., Statham, P. J. \& Crawford, D. W. Total dissolved zinc in the upper water column of the subarctic North East pacific. Deep-Sea Res. II 49, 5793-5808 (2002).

19. Duce, R. et al. The atmospheric input of trace species to the world ocean. Glob. Biogeochem. Cycles 5, 193-259 (1991).

20. Liu, X. \& Millero, F. J. The solubility of iron in seawater. Mar. Chem. 77, 43-54 (2002).
21. DOE. Handbook of Methods for the Analysis of the Various Parameters of the Carbon Dioxide System in Seawater (eds Dickson, A. G. \& Goyet, C.) Version 2.1 ORNL/CDIAC-74 〈http://andrew.ucsd.edu/ co2qc/handbook.html $\rangle$ (1994)

22. Pettit, L. D. \& Powell, K. J. IUPAC Stability Constants Database (IUPAC and Academic Software, Otley, 2001).

23. Millero, F. J. \& Pierrot, D. A chemical equilibrium model for natural waters. Aquat. Geochem. 4, 153-199 (1998).

24. Sunda, W. \& Huntsman, S. Effect of $\mathrm{pH}$, light, and temperature on Fe-EDTA chelation and Fe hydrolysis in seawater. Mar. Chem. 84, 35-47 (2003).

25. Mehrbach, C., Culberson, C. H., Hawley, J. E. \& Pytkowicz, R. N. Measurement of the apparent dissociation constants of carbonic acid in seawater at atmospheric pressure. Limnol. Oceanogr. 18, 897-907 (1973).

26. Dickson, A. G. \& Millero, F. J. A comparison of the equilibrium constants for the dissociation of carbonic acid in seawater media. Deep-Sea Res. 34, 1733-1743 (1987).

27. Stoll, M. H. C., Bakker, K., Nobbe, G. H. \& Haese, R. R. Continuous flow analysis of dissolved inorganic carbon content in seawater. Anal. Chem. 73, 4111-4116 (2001).

28. Candelone, J.-P., Hong, S., Pellone, C. \& Boutron, C. F. Post-Industrial Revolution changes in largescale atmospheric pollution of the northern hemisphere by heavy metals as documented in central Greenland snow and ice. J. Geophys. Res. 100, 16605-16616 (1995).

29. Hong, S., Candelone, J.-P. \& Boutron, C. F. Changes in zinc and cadmium concentrations in Greenland ice during the past 7760 years. Atmos. Environ. 31, 2235-2242 (1997).

30. Hong, S., Candelone, J.-P., Turetta, C. \& Boutron, C. F. Changes in natural lead, copper, zinc and cadmium concentrations in central Greenland ice from 8250-149,100 years ago: their association with climate changes and resultant variations of dominant source contributions. Earth Planet. Sci. Lett. 143, 233-244 (1996).

Acknowledgements We thank A. Terbrüggen, K.-U. Richter and B. van der Wagt for laboratory assistance, and M. Lohan, K. W. Bruland and R. E. Zeebe for discussions during the preparation of this manuscript. This work was partly funded by the German Research Foundation (DFG).

Competing interests statement The authors declare that they have no competing financial interests.

Correspondence and requests for materials should be addressed to K.G.S.

(kschulz@ifm-geomar.de).

\section{Aggression by polyembryonic wasp soldiers correlates with kinship but not resource competition}

\section{David Giron $^{1}$, Derek W. Dunn ${ }^{2}$, Ian C. W. Hardy ${ }^{2}$ \& Michael R. Strand ${ }^{1}$}

${ }^{1}$ Department of Entomology, University of Georgia, Athens, Georgia 30602, USA ${ }^{2}$ School of Biosciences, University of Nottingham, Sutton Bonington Campus, Loughborough LE12 5RD, UK

Kin selection theory predicts that individuals will show less aggression and more altruism towards relatives $^{1,2}$. However, recent theoretical developments suggest that with limited dispersal, competition between relatives can override the effects of relatedness ${ }^{3-9}$. The predicted and opposing influences of relatedness and competition are difficult to approach experimentally because conditions that increase average relatedness among individuals also tend to increase competition. Polyembryonic wasps in the family Encyrtidae are parasites whose eggs undergo clonal division to produce large broods ${ }^{10}$. These insects have also evolved a caste system: some embryos in a clone develop into reproductive larvae that mature into adults, whereas others develop into sterile soldier larvae that defend siblings from competitors ${ }^{11-14}$. In a brood from a single egg, reproductive altruism by soldiers reflects clone-level allocation to defence at the cost of reproduction, with no conflict between individuals. When multiple eggs are laid into a host, inter-clone conflicts of interest arise. Here we report that soldier aggression in Copidosoma floridanum is inversely related to the genetic relatedness of competitors but shows no correlation with the level of resource competition.

Polyembryonic encyrtids are small $(1 \mathrm{~mm})$ parasitoid wasps that 